\title{
STRUCTURAL AND PRODUCTIVE FEATURES OF Panicum CULTIVARS SUBMITTED TO DIFFERENT REST PERIODS IN THE IRRIGATED SEMIARID REGION OF BRAZIL
}

\author{
CARACTERÍSTICAS ESTRUTURAIS E PRODUTIVAS EM CULTIVARES DE \\ Panicum SUBMETIDAS A INTERVALOS DE CORTE SOB IRRIGAÇÃO NO \\ SEMIÁRIDO
}

\section{Jacqueline dos Santos OLIVEIRA ${ }^{1}$; João Virgínio EMERENCIANO NETO ${ }^{2}$; Gelson dos Santos DIFANTE ${ }^{3}$; Fabio Nunes LISTA ${ }^{2}$; Rodrigo da Silva SANTOS ${ }^{4}$; Jessica Daisy do Vale BEZERRA ${ }^{5}$; Breno Ramon de Souza BONFIM ${ }^{5}$; Larissa Bezerra Soares MILHOMENS ${ }^{6}$; Juliani Stephanie Medeiros RIBEIRO ${ }^{7}$}

1. Mestranda em Zootecnia - Universidade Federal de Lavras, Lavras-MG, Brasil - jacquelineoliveira.czoo@gmail.com; 2. Professores do Colegiado de Zootecnia - Universidade Federal do Vale do São Francisco - UNIVASF, Petrolina - PE, Brasil; 3. Professor da Faculdade de Medicina Veterinária e Zootecnia - Universidade Federal do Mato Grosso do Sul, Campo Grande - MS, Brasil; 4. Graduando em Engenharia Agronômica - UNIVASF, Petrolina-PE, Brasil; 5. Graduandos em Zootecnia - UNIVASF, Petrolina-PE, Brasil; 6. Graduada em Ciências Biológicas - UNIVASF, Petrolina-PE, Brasil; 7. Mestranda em Ciência Animal - UNIVASF, Petrolina-PE, Brasil.

\begin{abstract}
The objective of this study was to evaluate the structural and productive features of Panicum maximum cultivars (Tanzânia, Mombaça, Massai, and Zuri) in three rest periods (30, 45 and 60 days), in the semiarid region of Brazil. The experiment was carried out in a completely randomized design with three replicates. The length of the leaf blade and the diameter of the stem increased as a function of the cut intervals. Leaf blade width and number of live leaves (3.86 leaves tiller ${ }^{-1}$ ) were not affected by cut intervals. The height of the canopy increased with the ages, with effect in the mass of forage, being the cv. Zuri the most productive with $148,75 \mathrm{~cm}$ e $18.297,49 \mathrm{~kg} \mathrm{ha}^{-1} \mathrm{DM}$ at 60 days. The highest masses of leaves and stems were obtained in the longest rest period, while the leaf/stem ratio decreased. In the cut-off interval of 45 days, the cultivars of Panicum maximum have shown satisfactory yield, and the smaller cut interval provides a reduction in canopy height and stem thickness.
\end{abstract}

KEYWORDS: Accumulation rate. Forage mass. Morphological composition.

\section{INTRODUCTION}

Pastures, the food base of beef and milk cattle, are of great importance for Brazilian cattle growth, since it has made the country the main meat exporter in the world (VALLE et al., 2009), where more than $83 \%$ of slaughter cattle are bred on pasture (FERRAZ; FELÍCIO, 2010). Despite the importance of forage plants, it is estimated that more than $70 \%$ of cultivated pastures are at some stage of degradation (MACEDO et al., 2014), and inadequate management of grazing is one of the leading causes of this process (DIAS-FILHO, 2011).

The practice of defoliation requires adequate monitoring through grazing management to ensure an optimal balance between growth, senescence and consumption processes, to allow high-quality forage production and pasture persistence (SILVA, 2004). The equilibrium of the defoliation can be adjusted using combinations between interval and intensity (SANTOS et al., 2010a). According to Lara et al. (2012), in spite of the growing number of studies that use light canopy interception as a criterion for grazing management, for modeling purposes and/or growth potential and morphological composition dynamics, the traditional methods based on fixed periods of rest are valuable in the construction of databases for a given environment. As using the methods based on fixed rest periods, the differences in growth potential and morphological composition dynamics can be attributed to the evaluated treatments.

Among the forage crops, the Panicum genus has been outstanding for use in irrigated areas (VOLTOLINI et al., 2011), since they are widely known for their productivity, quality and adaptation to different soil and climatic conditions. It is considered the most productive species among tropical forage propagated by seeds and has been widely used for its abundant production of long leaves, high growth form, and high acceptability by the animals (JANK et al., 2010). However, there is a lack of information in the literature on the grazing 
management of these grasses in the semiarid environment.

In this context, we aimed to evaluate the effect of the rest periods on the structural and productive features in cultivars of Panicum maximum in the semiarid environment, and under irrigation.

\section{MATERIAL AND METHODS}

The experiment was performed between August/2016 and June/2017 in the agronomic field of the Agricultural Sciences Campus, of the Federal University of the São Francisco Valley, located in the municipality of Petrolina-PE (09' 19' 24" South and $40^{\circ} 33^{\prime}$ 34" West, at an altitude of $391 \mathrm{~m}$ $(1282,81 \mathrm{ft}))$. The climate, according to the Köppen classification, is of $\mathrm{BSh}$ type, with an average annual temperature of $26^{\circ} \mathrm{C}\left(78,8^{\circ} \mathrm{F}\right)$ and average annual precipitation of $435 \mathrm{~mm}(14,709.1 \mathrm{oz})$. Precipitation and temperature data (Figure 1) were collected at a meteorological station located $50 \mathrm{~m}$ from the experimental area.

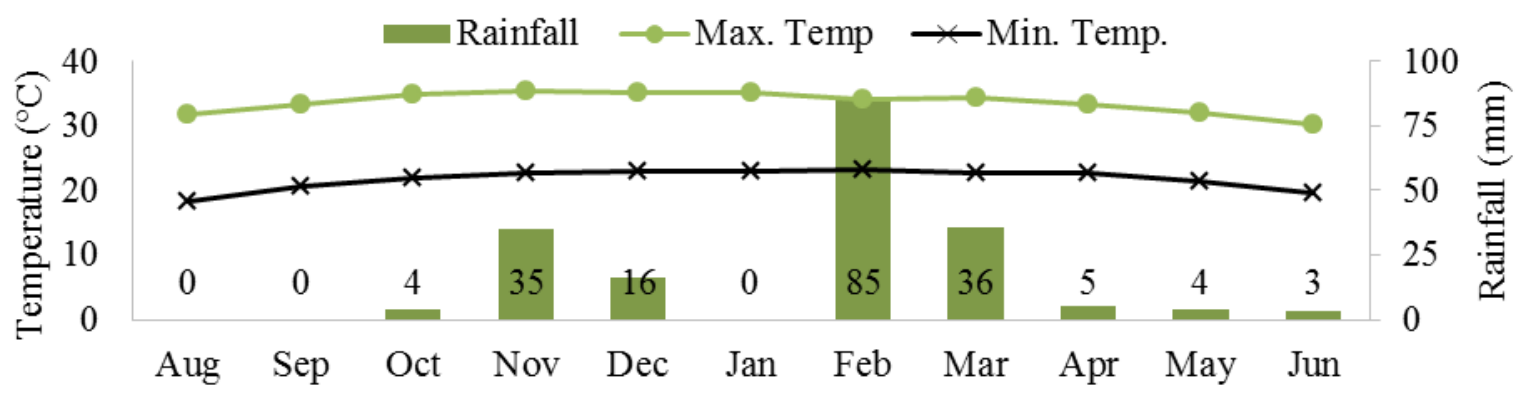

Figure 1. Rainfall, maximum and minimum temperatures from August 2016 to June 2017.

The soil in the area was classified as Yellow Argissoil, with medium/sandy texture (EMBRAPA, 2006). Before the beginning of the experiment, soil samples were collected in the $0-20 \mathrm{~cm}$ layer and submitted for chemical analysis (Table 1). There was no need for acidity and fertility correction; only fertilization was performed in the cover, applying $150 \mathrm{~kg} / \mathrm{ha} /$ year of $\mathrm{N}$, in the form of urea, which was divided into three applications, one every two cycles of evaluation.

Table 1. Soil chemical characteristics in the $0-20 \mathrm{~cm}$ layer.

\begin{tabular}{cccccccccc}
\hline \multirow{2}{*}{$\mathrm{pH}$} & \begin{tabular}{c}
$\mathrm{P}$ \\
\cline { 3 - 8 }
\end{tabular} & $\mathrm{Ca}$ & $\mathrm{Mg}$ & $\mathrm{K}$ & $\mathrm{Na}$ & $\mathrm{H}+\mathrm{Al}$ & $\mathrm{Al}$ & $\mathrm{CEC}$ & $\begin{array}{c}\mathrm{BSS} \\
(\%)\end{array}$ \\
\hline 5.7 & 20.22 & 1.5 & 0.8 & 0.36 & 2.17 & 1.16 & 0.0 & 5.98 & 81 \\
\hline
\end{tabular}

CEC: cation exchange capacity; BS: Base saturation

The experimental design was completely randomized, with a scheme of measures repeated in the time (cuts), being the treatments four cultivars of Panicum maximum Jacq. (Tanzânia, Mombaça, Massai and Zuri) submitted to three cut intervals based on fixed rest periods (30, 45 and 60 days). The cut intensity for all treatments was $25 \mathrm{~cm}$ of the height of the residue, as recommended by Difante et al. (2010). The experimental area used was $30 \mathrm{~m}^{2}$, subdivided into 12 experimental units of $2.5 \mathrm{~m}^{2}(2.5$ $\mathrm{x} 1.0 \mathrm{~m}$ ), three for each cultivar (replicates).

The cultivars were established in September 2015. Before the beginning of the experiment, the plants were managed with 30-day cut intervals, and the area weed-free was maintained through manual weeding. Irrigation was done daily by a microsprinkler system ( $\left.3 \mathrm{~h} \mathrm{day}^{-1}\right)$, using two microsprinklers per plot, with a flow rate of $50 \mathrm{~L} \mathrm{~h}^{-1}$ each.
Before the beginning of the evaluations, a standardization cut in the plants was performed at a height of $25 \mathrm{~cm}$ of the level of the ground in all the experimental units. Excluding the standardization cut, the cuts performed for each interval were at 30 , 45 and 60 days.

Before each cut, the height of the canopy was measured with a rod, graduated in centimeters, at three representative points of each plot. Canopy height was considered from the ground level to the average curvature of the leaves. The plants were then cut to $25 \mathrm{~cm}$ from the soil and taken to the laboratory where the fresh mass was determined. Soon afterward, subsamples were collected and separated manually in leaf blades and stems (stem + sheath). These samples were conditioned separately in paper bags, weighed and placed in a greenhouse with forced air circulation, at $55^{\circ} \mathrm{C}$ for 72 hours, in 
order to determine the dry matter (DM) content and to estimate the forage mass and of each of the components morphological $\left(\mathrm{kg} \mathrm{ha}^{-1} \mathrm{DM}\right)$. From this, the mass of leaf blades and stems were calculated, and the leaf blade/stem ratio was determined by the ratio between the dry mass of leaves and the dry mass of stems. The morphological components accumulation rates were determined by the ratio between the mass of each component, and the rest period, expressed as $\mathrm{kg}_{\mathrm{g}}$ hay ${ }^{-1} \mathrm{DM}$.

The evaluation of the structural features was performed by three representative tillers, from other subsamples. In these, the length and width of the leaf blade, stem diameter, and the number of live leaves were measured. The dimensions of the leaf blade were measured in the last expanded leaf of the tiller, with the aid of a digital caliper. The length of the leaf blade was given by the distance between the leaf tip and its ligule. The width of the leaf blade was measured in the central part of the leaf and the diameter of the stem was obtained in the middle of this organ. The number of live leaves consisted of the number of expanding and expanded leaves of each tiller, disregarding the leaves that had more than $50 \%$ of the senescent leaf blade, being classified as dead.

Data were submitted to analysis of variance and the means of the treatments and the effect of the interaction compared by the Tukey test to $5 \%$ of significance, through the statistical program
SISVAR 5.6 (FERREIRA, 2011). The following statistical model was used: Yijk $=\mu+\mathrm{Ci}+\alpha \mathrm{ij}+\mathrm{Fk}$ $+(\mathrm{CF}) \mathrm{ij}+\beta \mathrm{ijk}$, where: Yijk $=$ value observed in cultivar $\mathrm{i}$, interval $\mathrm{k}$, repetition $\mathrm{j} ; \mu=$ general mean effect; $\mathrm{Ci}$ = effect of cultivar i (Tanzânia, Mombaça, Massai and Zuri); $\alpha \mathrm{ij}=$ effect of the random error attributed to the plot; $\mathrm{Fk}=$ effect of cut interval $\mathrm{k}$ (30, 45 and 60 days); (CF) ij = effect of interaction between cultivar $\mathrm{i}$ and interval $\mathrm{k} ; \beta \mathrm{ijk}=$ random error attributed to the sub-plot.

\section{RESULTS AND DISCUSSION}

The interaction between rest periods and cultivars was not significant $(\mathrm{P}>0.05)$ for leaf blade length and width, stem diameter and number of live leaves. When comparing the cultivars, we observed a significant difference $(\mathrm{P}<0.05)$ for leaf blade length, leaf blade width and stem diameter. Cvs. Mombaça, Tanzânia, and Zuri presented values similar to each other and higher than cv. Massai. This latter cultivar obtained the lowest values for these parameters (Table 2). These results are related to the features inherent to each cultivar. Some of them have thicker stems, larger leaves, and larger ones, as in the case of Tanzânia, Mombaça, and Zuri, while others are smaller, presenting thinner stems and narrower leaves, such as Massai (JANK et al., 2010).

Table 2. Structural features of Panicum maximum cultivars submitted to rest periods.

\begin{tabular}{lccccc}
\hline \multicolumn{1}{c}{ Variable } & Massai & Mombaça & Tanzânia & Zuri & SEM \\
\hline Length of leaf blade $(\mathrm{cm})$ & $57.45 \mathrm{~b}$ & $97.61 \mathrm{a}$ & $86.06 \mathrm{a}$ & $93.24 \mathrm{a}$ & 4.35 \\
Width of leaf blade $(\mathrm{cm})$ & $1.08 \mathrm{~b}$ & $3.64 \mathrm{a}$ & $3.42 \mathrm{a}$ & $3.34 \mathrm{a}$ & 0.08 \\
Diameter of the stem $(\mathrm{cm})$ & $0.32 \mathrm{~b}$ & $0.93 \mathrm{a}$ & $0.94 \mathrm{a}$ & $1.02 \mathrm{a}$ & 0.03 \\
Number of live leave (leave tiller $^{-1}$ ) & $3.53 \mathrm{a}$ & $3.93 \mathrm{a}$ & $3.90 \mathrm{a}$ & $4.13 \mathrm{a}$ & 0.16 \\
\hline
\end{tabular}

SEM, Standard error mean. Averages followed by distinct letters on the line differ from one another by the Tukey test $(\mathrm{P}<0.05)$.

Gomes et al. (2011), evaluating 23 genotypes of $P$. maximum, found much lower values than those of the present study for length $(54.56$, 68.26 and $48.97 \mathrm{~cm})$ and leaf blade width $(0.84$, 2.12 and $1.78 \mathrm{~cm}$ ) in the cultivars Massai, Mombaça and Tanzânia, respectively. These lower values can be due to the absence of cover fertilization, variation in rainfall and lower cut interval adopted by the authors.

Working with Zuri grass under salinity and irrigation slides, Camilo (2017) found maximum values of 62.68 and $3.04 \mathrm{~cm}$ for leaf length and width, respectively, under high water availability (120\% of evapotranspiration). This lower length observed by the author may be associated with the height (10 cm of the soil) and frequency of cut (28 days) adopted, which resulted in a lower sprout capacity and, consequently, lower leaf growth. According to Gomide et al. (2002), the residual leaf area after cutting or grazing plays a fundamental role in promoting new growth, as it influences the photosynthetic capacity and speed of recovery of pasture.

The number of live leaves (NLL) was not affected by any of the sources of variation $(\mathrm{P}>$ 0.05 ), with a mean of 3.86 leaves tiller ${ }^{-1}$ (Tables 2 and 3). The absence of a cut-off effect may be due to the low variations in climatic conditions throughout the experiment, which may have been insufficient to modify this variable. Fagundes et al. (2006), evaluating morphogenetic and structural features of tropical pastures, reported that variations 
in the number of live leaves occurred due to changes in environmental conditions when they observed higher values during rainy season for this parameter.

Santos et al. (2011) also did not verify plant height effects on the number of live leaves in $B$. decumbens $\mathrm{cv}$. Basilisk. The authors suggest that these results are due, in part, to the phenotypic plasticity of the grass, which allows the alteration of its morphogenesis to maintain a stable number of leaves alive. The values obtained in the present study for the number of live leaves are similar to those found by Gomide and Gomide (2000) for cvs. Tanzânia and Mombaça (3.5 leave tiller ${ }^{-1}$ ), by Luna et al. (2014) for cv. Massai (4.11 leave tiller $\left.{ }^{-1}\right)$ and by Camilo (2017) to the Zuri grass (3.4 leave tiller $\left.{ }^{1}\right)$.

The leaf length was affected by the cut intervals $(\mathrm{P}<0.05)$, with an increase in length as the cut interval increased, with the highest values obtained at 45 and 60 days of rest (Table 3). This result can be due to the longer shoots observed in the plants harvested at larger intervals have longer shoots. According to Casagrande et al. (2010), the length of the stem has a direct influence on the growth of the leaf, since it determines the space to be covered by it for its emergence and expansion.

Table 3. Effect of rest period on the structural characteristics of Panicum maximum cultivars.

\begin{tabular}{lcccc}
\hline \multicolumn{1}{c}{ Variable } & 30 & 45 & 60 & SEM \\
\hline Length of leaf blade $(\mathrm{cm})$ & $70.51 \mathrm{~b}$ & $91.34 \mathrm{a}$ & $92.80 \mathrm{a}$ & 3.97 \\
Width of leaf blade $(\mathrm{cm})$ & $2.91 \mathrm{a}$ & $2.82 \mathrm{a}$ & $2.86 \mathrm{a}$ & 0.08 \\
Diameter of the stem $(\mathrm{cm})$ & $0.70 \mathrm{c}$ & $0.81 \mathrm{~b}$ & $1.00 \mathrm{a}$ & 0.03 \\
Number of live leave $\left(\right.$ leave tiller $\left.^{-1}\right)$ & $3.87 \mathrm{a}$ & $3.75 \mathrm{a}$ & $3.94 \mathrm{a}$ & 0.15 \\
\hline
\end{tabular}

SEM, Standard error mean. Averages followed by distinct letters on the line differ from one another by the Tukey test $(\mathrm{P}<0.05)$.

The leaf blade width was not influenced by the cut intervals $(\mathrm{P}>0.05)$, with a mean of $2.86 \mathrm{~cm}$. According to Silva et al. (2010), leaf length and width are related to leaf area index (LAI), which indicates the ability of the canopy to intercept sunlight for photosynthesis and generate energy for plant maintenance and growth. In this way, these variables are determinant for obtaining higher dry matter yields (COSTA et al., 2009), since larger leaf blades have a more considerable amount of tissue, which contributes to the higher total forage mass (SANTOS et al., 2010b).

The stem diameter varied according to the cut intervals $(\mathrm{P}<0.05)$, with a lower value at 35 days and greater at 60 days of rest (Table 3). Castagnara et al. (2011), evaluating the structural features of tropical grasses under nitrogen fertilization, found an average value of $1.17 \mathrm{~cm}$ in diameter at 42 days of rest in Panicum maximum cultivars, greater than the results observed even at 60 days. According to the authors, the development of the stem occurs as a consequence of the growth of the canopy, in order to give the plant greater sustentation.

The effect of the interaction between cultivars and cut intervals was significant $(\mathrm{P}<0.05)$ for canopy height and forage mass. In all cultivars, a positive correlation was observed between canopy height and cut intervals, with the highest values at 60 days of rest (Table 4). This result was expectable since plants submitted to more extended rest periods have their heights increased. The cvs which obtained the highest heights were Zuri and Tanzânia at 30 days, and cvs. Zuri, Tanzânia, and Mombaça at 45 days compared to the Massai grass, which presented the lowest values for this parameter at all intervals. At 60 days of rest, Zuri grass had the highest height $(148.75 \mathrm{~cm})$.

Table 4. Height of forage canopy and forage mass in Panicum maximum cultivars submitted to rest periods.

\begin{tabular}{ccccc}
\hline Rest period (day) & Massai & Mombaça & Tanzânia & Zuri \\
\hline & & Canopy height $(\mathrm{cm})(\mathrm{SEM}=2.02)$ & \\
40 & $57.33 \mathrm{Bc}$ & $67.38 \mathrm{Abc}$ & $74.17 \mathrm{Ac}$ & $77.56 \mathrm{Ac}$ \\
60 & $76.67 \mathrm{Bb}$ & $109.17 \mathrm{Ab}$ & $98.67 \mathrm{Ab}$ & $105.50 \mathrm{Ab}$ \\
& $102.17 \mathrm{Ca}$ & $143.00 \mathrm{Aba}$ & $130.58 \mathrm{Ba}$ & $148.75 \mathrm{Aa}$ \\
30 & $2653.48 \mathrm{Ab}$ & $2618.05 \mathrm{Ab}$ & $3163.39 \mathrm{Ab}$ & $5613.30 \mathrm{Ab}$ \\
45 & $6186.87 \mathrm{Aab}$ & $5776.78 \mathrm{Ab}$ & $6250.86 \mathrm{Ab}$ & $10026.06 \mathrm{Ab}$ \\
60 & $8687.24 \mathrm{Ba}$ & $10273.48 \mathrm{Ba}$ & $11736.09 \mathrm{Ba}$ & $18297.49 \mathrm{Aa}$ \\
\hline
\end{tabular}

SEM, Standard error mean. Averages followed by distinct letters on the line differ from one another by the Tukey test $(\mathrm{P}<0.05)$. 
These results suggest that pastures harvested at intervals of 45 and 60 days showed greater interception of light (IL) than recommended (95\% IL), corresponding to pre-grazing heights: 70 cm for Tanzânia grass (BARBOSA et al., 2007), 90 $\mathrm{cm}$ for the Mombaça grass (CARNEVALLI et al., 2006), $55 \mathrm{~cm}$ for the Massai grass (BARBOSA et al., 2010) and 70 to $75 \mathrm{~cm}$ for Zuri grass (EMBRAPA, 2014). Light interception is challenging to assess, but its correspondence with pasture height allows this parameter to be used in practical conditions to guide grazing management. Thus, the shorter cut interval (30 days) provided a reduction in the canopy height, besides the possibility of using the pasture in a higher number of grazing cycles.

The highest yields of forage mass were obtained at 60 days in comparison to the other cut intervals $(\mathrm{P}<0.05)$. Among the cultivars, there was a significant difference $(\mathrm{P}<0.05)$ only in the 60 days interval, when $\mathrm{cv}$. Zuri was more productive $\left(18,297.49 \mathrm{~kg} \mathrm{ha}^{-1} \mathrm{DM}\right)$ than the others (Table 4). We confirmed that the forage mass behaved in a similar form as observed for the canopy height, showing an increasing effect with the development of the plant, which provided greater forage accumulation with the increase of the cut interval. Stabile et al. (2010), when evaluating cvs. Massai, Mombaça, and Tanzânia observed lower values for dry matter production at 60 days of growth (7067, 4432 and $3734 \mathrm{~kg} \mathrm{ha}^{-1} \mathrm{DM}$, respectively). The use of irrigation and cover fertilization carried out in this work can explain these results, contributing to higher yields.

The interaction between cut intervals and cultivars was significant $(\mathrm{P}<0.05)$ for the masses of the morphological components, as well as for the leaf/stem ratio (Table 5).

Table 5. Morphological composition and leaf blade/stem ratio in Panicum maximum cultivars submitted to rest periods.

\begin{tabular}{|c|c|c|c|c|}
\hline Rest period (day) & Massai & Mombaça & Tanzânia & Zuri \\
\hline & \multicolumn{4}{|c|}{ Leaf blade mass $\left(\mathrm{kg} \mathrm{ha}^{-1} \mathrm{DM}\right)(\mathrm{SEM}=635.47)$} \\
\hline 30 & $1554.53 \mathrm{Ba}$ & $1972.58 \mathrm{ABb}$ & $2291.79 \mathrm{ABb}$ & $4129.31 \mathrm{Ab}$ \\
\hline 45 & $4319.32 \mathrm{Aa}$ & $4058.82 \mathrm{Aab}$ & $4338.91 \mathrm{Aab}$ & 6804.71Aab \\
\hline 60 & $3000.66 \mathrm{Ba}$ & $5217.43 \mathrm{ABa}$ & 7096.00Aa & $8091.99 \mathrm{Aa}$ \\
\hline \multicolumn{5}{|c|}{ Stem mass $\left(\mathrm{kg} \mathrm{ha}{ }^{-1} \mathrm{DM}\right)(\mathrm{SEM}=480.73)$} \\
\hline 30 & $1098.95 \mathrm{Ab}$ & $645.47 \mathrm{Aa}$ & $871.60 \mathrm{Ab}$ & $1483.99 \mathrm{Ab}$ \\
\hline 45 & $1867.55 \mathrm{Ab}$ & $1717.97 \mathrm{Aa}$ & $1911.95 \mathrm{Ab}$ & $3221.35 \mathrm{Ab}$ \\
\hline 60 & $5686.59 \mathrm{Ba}$ & $5056.04 \mathrm{Ba}$ & $4640.09 \mathrm{Ba}$ & $10205.49 \mathrm{Aa}$ \\
\hline & \multicolumn{4}{|c|}{ Relation leaf blade/stem $(\mathrm{SEM}=0.22)$} \\
\hline 30 & $1.72 \mathrm{Ba}$ & $2.70 \mathrm{Aa}$ & $2.39 \mathrm{ABa}$ & $2.57 \mathrm{ABa}$ \\
\hline 45 & 2.09Aa & $2.17 \mathrm{Aab}$ & $2.10 \mathrm{Aa}$ & $2.02 \mathrm{Aa}$ \\
\hline 60 & $0.59 \mathrm{Ab}$ & $1.18 \mathrm{Ab}$ & $1.48 \mathrm{Aa}$ & $0.79 \mathrm{Ab}$ \\
\hline
\end{tabular}

SEM, Standard error mean. Averages followed by distinct letters, upper case in the row and lowercase in the column, differ by Tukey test $(\mathrm{P}<0.05)$.

In general, the values observed for the masses of the morphological components (leaf blade and stem) were similar to those obtained for the forage mass, increasing with the extension of the cut interval (Table 5). At 30 days, the leaf blade mass was higher for cv. Zuri when compared to the Massai grass $(\mathrm{P}<0.05)$. There was no difference between cultivars for this parameter at 45 days $(\mathrm{P}>$ 0.05). On the other hand, within 60 days, cvs. Tanzânia and Zuri were more productive $(\mathrm{P}<0.05)$ than the Massai grass.

The stem mass did not differ $(\mathrm{P}>0.05)$ between the cultivars in the intervals of 30 and 45 days. However, at 60 days of rest, the stem mass was higher $(\mathrm{P}<0.05)$ for Zuri grass, when compared to the other cultivars. This difference indicates that, after 45 days, the Zuri grass continues to grow intensely, producing more stem than leaves.

Barbosa et al. (2007), working with Tanzânia grass in Mato Grosso do Sul, found, for the same height of residue $(25 \mathrm{~cm}$ of soil), leaf blades masses of 9,000 and $10,560 \mathrm{~kg} \mathrm{ha}^{-1} \mathrm{DM}$, respectively, for canopies with 90 and $95 \%$ of interception of light, values that are well superior to those of the present work. These results can be due to the higher nitrogen dose used by the authors (200 $\mathrm{kg} \mathrm{ha}{ }^{-1} \mathrm{~N}$ ), which may have led to the more significant development of pasture.

The leaf/stem ratio decreased as increasing the cutting age $(\mathrm{P}<0.05)$. The highest values for the leaf/stem ratio were obtained in the intervals of 30 and 45 days in all the cultivars, except for the Tanzânia grass, which presented no difference for 
this parameter as a function of the cut intervals. There was no significant difference ( $P>0.05$ ) between the cultivars for this characteristic at 45 and 60 days of age. On the other hand, within 30 days, cv. Mombaça obtained the highest value $(\mathrm{P}<0.05)$ for the blade/stem ratio when compared to the $\mathrm{cv}$. Massai.

We considered these results satisfactory: the leaf blade ratio was, on average, twice as high as the stem, exceeding the threshold considered critical for this relationship (1.0). Only cvs. Massai and Zuri presented values below the critical level (at 60 days). According to Brâncio et al. (2003), leaf blade ratio lower than the critical values causes a reduction in quantity and quality of the forage produced, being able to negatively influence the structure of the pasture and the efficiency of the grazing animals.

We observed the higher rate of leaves blade accumulation (LBAR) in the cv. Zuri at 30 and 45 days of the aftermath. At 60 days of aftermath, cv. Massai displayed a lower rate than cvs. Zuri and Tanzânia (Table 6). All cvs., except Tanzânia, displayed lower LBAR at 60 days than at 45. These results highlight that from the 45 days of the aftermath on; the pasture already reached the maximum number of living leaves per tiller, and the equilibrium between the appearance and senescence of the leaves (SIMIONI et al., 2014). At this point, the aftermath period shall be interrupted by defoliation or cut, in order to avoid the excessive accumulation of stem and senescent material in the canopy (CUTRIM JUNIOR et al., 2011). The resemblance between the LBAR of the cv Massai at 60 days with $33.4 \mathrm{~kg}$ ha day $^{-1} \mathrm{DM}$ described by Emerenciano Neto et al. (2017) in grazing lands of this cultivar harvested by sheep with a 86 days interval confirms the equilibrium between the apparence and senescence of the leaves described previously.

Table 6. Morphological components accumulation rate in Panicum maximum cultivars submitted to rest periods.

\begin{tabular}{|c|c|c|c|c|}
\hline Rest period (day) & Massai & Mombaça & Tanzânia & Zuri \\
\hline \multicolumn{5}{|c|}{ Leaf blade accumulation rate $\left(\mathrm{kg}^{3}\right.$ hay $\left.^{-1} \mathrm{DM}\right)(\mathrm{SEM}=8.82)$} \\
\hline 30 & $51,82 \mathrm{Bb}$ & $65,75 \mathrm{Bab}$ & $76.39 \mathrm{Ba}$ & $137.64 \mathrm{Aa}$ \\
\hline 45 & $95,98 \mathrm{Ba}$ & $90.19 \mathrm{Ba}$ & $96.42 \mathrm{Ba}$ & 151.21Aa \\
\hline 60 & $34,29 \mathrm{Bb}$ & $48.65 \mathrm{ABb}$ & $62.45 \mathrm{Aa}$ & $70.27 \mathrm{Ab}$ \\
\hline \multicolumn{5}{|c|}{ Stem accumulation rate $(\mathrm{kg}$ ha day $\mathrm{DM})(\mathrm{SEM}=6.08)$} \\
\hline 30 & $36.63 \mathrm{ABb}$ & $21.51 \mathrm{Bb}$ & $29.05 \mathrm{ABb}$ & $49.46 \mathrm{Ab}$ \\
\hline 45 & $41.50 \mathrm{Aab}$ & 38.18Aa & $42.48 \mathrm{Aa}$ & $71.58 \mathrm{Aab}$ \\
\hline 60 & $68.82 \mathrm{ABa}$ & $47.63 \mathrm{Ba}$ & $41.73 \mathrm{Ba}$ & $96.83 \mathrm{Aa}$ \\
\hline
\end{tabular}

SEM, Standard error mean Averages followed by distinct letters, upper case in the row and lowercase in the column, differ by Tukey test $(\mathrm{P}<0.05)$.

At the $45^{\text {th }}$ day of the aftermath we could not observe any difference among the different cvs. as refers to the stem accumulation rate (SAR). At the other intervals, the SAR of the cv. Zuri was higher than cv. Mombaça. We observed the highest SAR at 60 days of aftermath, as compared to 45 days aftermath interval. This result is associated with the height of the canopy (Table 4), as the is the structural component of the plant, and its growth depends on the growth of the plant itself.

The results obtained in this study suggest that the cutting or grazing of these cultivars should be done with shorter rest periods (30 or 45 days), providing greater leaf accumulation and less accumulation of stem and dead material, which, according to Difante et al. (2010), impair the nutritional quality of forage and make it difficult to apprehend animals grazing.

\section{CONCLUSIONS}

The cultivars of Panicum studied in this paper displayed adequated production rates in the irrigated semiarid region as harvested at intervals of up to 45 days. At these rest periods, the forage displayed high production of leaves blades.

Among the cultivars studied, cv. Zuri shall be highlighted for its higher productivity. For this reason, its use shall be suggested in intensive production systems, which require a higher mass of forage to sustain animal productivity.

RESUMO: Objetivou-se avaliar as características estruturais e produtivas de cultivares de Panicum maximum (Tanzânia, Mombaça, Massai e Zuri) em periodos de descanso (30, 45 e 60 dias) no semiárido 
brasileiro, sob irrigação. O experimento foi realizado em delineamento inteiramente ao acaso, com três repetições. O comprimento da lâmina foliar e o diâmetro do colmo aumentaram em função dos intervalos de corte. A largura da lâmina foliar e o número de folhas vivas (3,86 folhas/perfilho) não foram afetados pelos intervalos de corte. A altura do dossel aumentou com as idades, com efeito na massa de forragem, sendo a cv. Zuri superior com 148,75 cm e 18.297,49 kg/ha de MS, aos 60 dias. As maiores massas de lâminas e colmos foram obtidas no maior período de rebrotação, enquanto que a relação folha/colmo diminuiu. No intervalo de corte de 45 dias, as cultivares de Panicum maximum apresentaram produção satisfatória, sendo que o menor intervalo de corte proporciona redução na altura do dossel e na espessura do colmo.

PALAVRAS-CHAVE: Composição morfológica. Massa de forragem. Taxa de acúmulo.

\section{REFERENCES}

BARBOSA, R. A.; NASCIMENTO JÚNIOR, D.; EUCLIDES, V. P. B; SILVA, S. C. DA ZIMMER, A. H.; TORRES JÚNIOR, R. A. A. Capim-tanzânia submetido a combinações entre intensidade e frequiência de pastejo. Pesquisa Agropecuária Brasileira, Brasília, v. 42, n. 3, p. 329-340, mar. 2007. https://doi.org/10.1590/S0100-204X2007000300005

BARBOSA, R. A.; ROSA, P. R.; LIMA, G. O. Capim-massai manejado em diferentes combinações de intensidade e frequência de corte. In: REUNIÃO ANUAL DA SOCIEDADE BRASILEIRA DE ZOOTECNIA, 47., 2010, Salvador. Anais... Salvador: SBZ, 2010. (CD-ROM).

BRÂNCIO, P. A.; EUCLIDES, V. P. B.; NASCIMENTO JÚNIOR, D.; FONSECA, D. M.; ALMEIDA, R. G.; MACEDO, M. C. M.; BARBOSA, R. A. Avaliação de três cultivares de Panicum maximum Jacq. sob pastejo: disponibilidade de forragem, altura do resíduo pós-pastejo e participação de folhas, colmos e material morto. Revista Brasileira de Zootecnia, Viçosa, v. 32, n. 1, p. 55-63, jan./fev. 2003.

http://doi.org/10.1590/S1516-35982003000100007

CAMILO, Danilo de Araújo. Morfofisiologia e trocas gasosas do capim Panicum maximum BRS Zuri sob salinidade e lâminas de irrigação. 2017. 117 f. Tese (Doutorado em Zootecnia) — Programa de Doutorado Integrado em Zootecnia, Universidade Federal do Ceará, Fortaleza. 2017.

CARNEVAlli, R. A.; SILVA, S. C.; OLIVEIRA, A. A.; UEBELE, M. C.; BUENO, F. O.; HODGSON, J.; MORAIS, J. P. G. Herbage production and grazing losses in Panicum maximum cv. Mombaça pastures under four grazing managements. Tropical Grasslands, Cali, v. 40, n. 3, p. 165-176, jan. 2006.

CASAGRANDE, D. R.; RUGGIERI, A. C.; JANUSCKIEWICZ, E. R.; GOMIDE, J. A.; REIS, R. A.; VALENTE, A. L. S. Características morfogênicas e estruturais do capim-marandu manejado sob pastejo intermitente com diferentes ofertas de forragem. Revista Brasileira de Zootecnia, Viçosa, v. 39, n. 10, p. 2108-2115, out. 2010. https://doi.org/10.1590/S1516-35982010001000002

CASTAGNARA, D. D.; MESQUISTA, E. E.; NERES, M. A.; OLIVEIRA, P. S. R.; DEMINICS, B. B.; BAMBERG, R. Valor Nutricional e características estruturais de gramíneas tropicais sob adubação nitrogenada. Arquivos de Zootecnia, Córdoba, v. 60, n. 232, p. 931-942, dez. 2011. http://doi.org/10.4321/S0004-05922011000400010

COSTA, N. L.; GIANLUPPI, V.; BENDAHAN, A. B.; BRAGA, R. M.; MATTOS, P. S. R. Fisiologia e Manejo de Gramíneas Forrageiras Tropicais. Boa Vista: Embrapa Roraima, 2009, 25p. (Embrapa Roraima. Documentos, 17).

CUTRIM JUNIOR, J. A. A. CÂNDIDO, M. J. D.; VALENTE, B. S. M.; CARNEIRO, M. S. S.; CARNEIRO, H. A. V. Características estruturais do dossel de capim-tanzânia submetido a três frequências de desfolhação e dois resíduos pós-pastejo. Revista Brasileira de Zootecnia, Viçosa, v. 40, n.3, p. 489-497, mar. 2011. http://doi.org/10.1590/S1516-35982011000300005 
DIAS-FILHO, M. B. Os desafios da produção animal em pastagens na fronteira agrícola brasileira. Revista Brasileira de Zootecnia, Viçosa, v. 40, p. 243-252, 2011.

DIFANTE, G. S.; EUCLIDES, V. P. B.; NASCIMENTO JÚNIOR, D.; SILVA, S. C.; BARBOSA, R. A.; TORRES JÚNIOR, R. A. A. Desempenho e conversão alimentar de novilhos de corte em capim Tanzânia submetido a duas intensidades de pastejo sob lotação rotativa. Revista Brasileira de Zootecnia, Viçosa, v. 39, n. 1, p. 33-41, jan. 2010. http://doi.org/10.1590/S1516-35982010000100005

EMERENCIANO NETO, J. V.; DIFANTE, G. S.; LANA, A. M. Q.; CAMPOS, N. R. F.; VERAS, E. L. L.; MORAES, J. D. Sward Structure and Herbage Accumulation of Massai Guineagrass Pastures Managed According to Pre-Grazing Heights, in the Northeast of Brazil. Journal of Agricultural Science, Toronto, v. 9, n. 4, p. 155-163, mar. 2017. http://doi.org/10.5539/jas.v9n4p155

EMPRESA BRASILEIRA DE PESQUISA AGROPECUÁRIA - EMBRAPA. Centro Nacional de Pesquisa de Solos. Sistema Brasileiro de Classificação de solos. 2. ed. Rio de Janeiro: Embrapa, 2006, 306p.

EMPRESA BRASILEIRA DE PESQUISA AGROPECUÁRIA - EMBRAPA. Centro Nacional de Pesquisas em Gado de Corte. BRS Zuri produção e resistência para pecuária. Campo Grande: Embrapa Gado de Corte, 2014.

FAGUNDES, J. L.; FONSECA, D. M.; MISTURA, C.; MORAIS, R. V.; VITOR, C. M. T.; GOMIDE, J. A.; NASCIMENTO JUNIOR, D.; CASAGRANDE, D. R.; COSTA, L. T. Características morfogênicas e estruturais do capim-braquiária em pastagem adubada com nitrogênio avaliadas nas quatro estações do ano.

Revista Brasileira de Zootecnia, Viçosa, v. 35, n. 1, p. 21-29, jan./fev. 2006. https://doi.org/10.1590/S151635982006000100003

FERRAZ, J. B. S.; FELÍCIO, P. E. Production systems - An example from Brazil. Meat science, v. 84, n. p. 238-243, fev. 2010. https://doi.org/10.1016/j.meatsci.2009.06.006

FERREIRA, D. F. Sisvar: a computer statistical analysis system. Ciência e Agrotecnologia, Lavras, v. 35, n. 6, p.1039-1042, nov./dez. 2011. https://doi.org/10.1590/S1413-70542011000600001

GOMES, R. A.; LEMPP, B.; JANK, L.; CARPEJANI, G. C.; MORAIS, M. G. Características anatômicas e morfofisiológicas de lâminas foliares de genótipos de Panicum maximum. Pesquisa Agropecuária Brasileira, Brasília, v. 46, n. 2, p. 205-211, fev. 2011. https://doi.org/10.1590/S0100-204X2011000200013

GOMIDE, C. A. M.; GOMIDE, J. A. Morfogênese de cultivares de Panicum maximum Jacq. Revista Brasileira de Zootecnia, Viçosa, v. 29, n. 2, p. 341-348, mar./abr. 2000. https://doi.org/10.1590/S151635982000000200004

GOMIDE, C. A. M.; GOMIDE, J. A.; HUAMAN, C. A. M.; PACIULLO, D. S. C. Fotossíntese, reservas orgânicas e rebrota do capim-mombaça (Panicum maximum Jacq.) sob diferentes intensidades de desfolha do perfilho principal. Revista Brasileira de Zootecnia, Viçosa, v. 31, n. 6, p. 2165-2175, nov./dez. 2002. https://doi.org/10.1590/S1516-35982002000900003

JANK, L.; MARTUSCELLO, J. A.; EUCLIDES, V. B. P.; VALLE, C. B.; RESENDE, R. M. S. Panicum maximum. In: FONSECA, D. M.; MARTUSCELLO, J. A. Plantas Forrageiras. 1. ed. Viçosa, MG: UFV, 2010. p. 166-196.

LARA, M. A. S.; PEDREIRA., C. G. S.; BOOTE, K. J.; PEDREIRA, B. C.; MORENO, L. S. B.; ALDERMAN, P. D. Predicting growth of Panicum maximum: an adaptation of the CROPGRO - Perennial Forage Model. Agronomy Journal, v. 104, n. 3, p. 600-611, mai. 2012. https://doi.org/10.2134/agronj2011.0272 
LUNA, A. A.; DIFANTE, G. S.; ARAÚJO, I. M. M.; LIMA, C. L. D.; EMERENCIANO NETO, J. V.; VASCONCELOS, R. I. G.; OLIVEIRA, H. C. B.; DANTAS, J. L. S. Características morfogênicas de gramíneas forrageiras no Nordeste do Brasil. Revista Científica de Produção Animal, Areia, v. 14, n. 2, p. 138-141, 2012. https://doi.org/10.15528/2176-4158/rcpa.v14n2p138-141

MACEDO, M. C. M.; ZIMMER, A. H.; KICHEL, A. N.; ALMEIDA, R. G. de; ARAUJO, A. R. de. Degradation of pastures, alternatives for recovery and renewal, and forms of mitigation. In: ENCONTRO DE ADUBAÇÃO DE PASTAGENS DA SCOT CONSULTORIA - TEC - FÉRTIL, 1., 2013, Ribeirão Preto, SP. Proccedings... Bebedouro: Scot Consultoria, 2014. p. 158-181.

SANTOS, N. L.; SILVA, V. C.; GALZERANO, L.; MEISTER, N. C.; MICELI, N. G. Manejo estratégico de pastagem para caprinos. Enciclopédia biosfera, Goiânia, v. 6, n. 10, p. 1-28, 2010a.

SANTOS, M. E. R.; AQUINO, R. F. S. F.; ROMÃO, M. C. Determinantes da morfologia da lâmina foliar de capim-elefante. Enciclopédia Biosfera, Goiânia, v. 6, n. 11, p. 1-10, 2010 b.

SANTOS, M. E. R.; FONSECA, D. M.; BRAZ, T. G. S.; SILVA, S. P.; GOMES, V. M.; SILVA, G. P. Características morfogênicas e estruturais de perfilhos de capim-braquiária em locais do pasto com alturas variáveis. Revista Brasileira de Zootecnia, Viçosa, v. 40, n. 3, p. 535-542, mar. 2011.

https://dx.doi.org/10.1590/S1516-35982011000300010

SILVA, S. C. Fundamentos para o manejo do pastejo de plantas forrageiras dos gêneros Brachiaria e Panicum. In: SIMPÓSIO SOBRE MANEJO ESTRATÉGICO DA PASTAGEM, 2., 2004. Anais... Viçosa: UFV, 2004, p. 347-385.

SILVA, A. L. C.; SANTOS, M. V. F.; DUBEUX JÚNIOR, J. C. B.; LIRA, M. A.; FERREIRA, R. L. C.; FREITAS, E. V.; CUNHA, M. V.; SILVA, M. C. Variabilidade e herdabilidade de caracteres morfológicos em clones de capim elefante na Zona da Mata de Pernambuco. Revista Brasileira de Zootecnia, Viçosa, v. 39, n.10, p. 2132-2140, out. 2010. https://doi.org/10.1590/S1516-35982010001000005

SIMIONI, T. A.; HOFFMANN, A.; GOMES, F. J. G.; MOUSQUER, C. J.; TEIXEIRA, U. H. G.;

FERNANDES, G. A.; BOTINI, L. A.; PAULA, D. C. Senescência, remoção, translocação de nutrientes e valor nutritivo em gramíneas tropicais. PUBVET, Londrina, v. 8, n. 13, art. 1743, jul. 2014.

STABILE, S. S.; SALAZAR, D. R.; JANK, L.; RENNÓ, F. P.; SILVA, L. F. P. Características de produção e qualidade nutricional de genótipos de capim- colonião colhidos em três estádios de maturidade. Revista Brasileira de Zootecnia, Viçosa, v. 39, n. 7, p. 1418-1428, jul. 2010. https://doi.org/10.1590/S15165982010000700004

VALLE, C. B.; JANK, L.; RESENDE, R. M. S. O melhoramento de forrageiras tropicais no Brasil. Revista Ceres, Viçosa, v. 56, n. 4, p. 460-472, jul./ago. 2009.

VOLTOLINI, T. V.; CAVALCANTI, A. C. R.; MISTURA, C.; CÂNDIDO, M. J. D.; SANTOS, B. R. C. Pasto e manejo do pastejo em áreas irrigadas. In: EMBRAPA (Ed.). Produção de ovinos e caprinos no Semiárido. 2011. p. 265-298. 